\title{
High-Performance Liquid Chromatographic Quantitative Determination of Amcinonide and Benzyl Alcohol in Pharmaceutical Preparations
}

\author{
Khalid Mohammed Khan ${ }^{*}, 1$, Abdul Rafiq Khan ${ }^{1}$, Shahnaz Perveen ${ }^{2}$, Zia-Ullah ${ }^{1}$, Nida Ambreen ${ }^{1}$ and \\ Wolfgang Voelter ${ }^{*}, 3$
}

\author{
${ }^{I}$ H.E.J. Research Institute of Chemistry, International Center for Chemical and Biological Sciences, University of \\ Karachi, Karachi-75270, Pakistan \\ ${ }^{2}$ PCSIR Laboratories Complex Karachi, Shahrah-e-Dr. Salimuz Zaman Siddiqui, Karachi-75280, Pakistan \\ ${ }^{3}$ Interfakultäres Institut für Biochemie der Universität Tübingen, Hoppe-Seyler Straße 4, D-72076, Tübingen, Germany
}

\begin{abstract}
This paper describes a simple, precise, and validated high-performance liquid chromatographic method for the simultaneous quantitative determination of amcinonide and benzyl alcohol in pharmaceutical preparations. The separation was achieved using a Zorbax reversed-phase column $(5 \mu \mathrm{m}, 250 \mathrm{x} 4.6 \mathrm{~mm})$ at room temperature with an isocratic mixture of deionized water and acetonitrile $(70: 30 \mathrm{v} / \mathrm{v})$ at a flow rate of $1.5 \mathrm{ml} / \mathrm{min}$ and detection at $254 \mathrm{~nm}$. The limits of quantification for amcinonide and benzyl alcohol were found to be $4-30 \mu \mathrm{g} / \mathrm{ml}$ and $80-600 \mu \mathrm{g} / \mathrm{ml}$, respectively. The validity of the method was evaluated in terms of linear regression analysis, precision, specificity, accuracy and ruggedness. The developed methodology is an economic, time-saving, straight forward and precise assay for the determination of amcinonide and benzyl alcohol in pharmaceutical preparations. It can be readily utilized for quality assurance and R\&D laboratories of pharmaceutical and cosmetic industry.
\end{abstract}

\section{INTRODUCTION}

Amcinonide is a corticosteroid applied as an antiinflammatory agent [1]. It is used in different pharmaceutical preparations such as film-forming creams, lotions and ointments for the treatment of skin disorders [2]. It exerts great influence on the structure and function of tail epidermis of yellow and black mice [3]. Amcinonide is used in pharmaceutical preparations alone or in combination with other steroids such as betamethasone valerate, hydrocortisone-17butyrate or flucinonide [4]. It is also mixed with some fungicides, used for mouthwashes [5]. Steroids have been used in pharmaceutical preparation since long to treat rheumatic, neoplastic and other disorders [6].

Amcinonide creams and ointments contain some preservative such as benzyl alcohol. Usually quantitative estimation of amcinonide and benzyl alcohol is done by two separate analytical methods. A high performance liquid chromatographic method with gradient elution of mobile phase is described for the quantification of amcinonide creams and of its raw materials [7]. A spectrophotometric method is also known for the determination of amcinonide in different pharmaceutical dosage forms which involves a lengthy extraction process followed by adsorption chromatography on silica gel as stationary phase and by spectrophotometric detection [8].

\footnotetext{
*Address correspondence to these authors at the (KMK) H.E.J. Research Institute of Chemistry, International Center for Chemical and Biological Sciences, University of Karachi, Karachi-75270, Pakistan;

E-mail: hassaan2@super.net.pk and (WV) Interfakultäres Institut für Biochemie der Universität Tübingen, Hoppe-Seyler Straße 4, D-72076, Tübingen, Germany; E-mail: wolfgang.voelter@uni-tuebingen.de
}

Application of thin layer chromatography to determine amcinonide in ointments and creams has been reported by several groups what proved to be a non-specific approach $[9,10]$. Simultaneous determination of hydrocortisone and benzyl alcohol in pharmaceutical formulations by reversed phase chromatography was also reported [11].

Benzyl alcohol is used as an antimicrobial preservative in pharmaceutical and cosmetic products and its concentration should not exceed limit values for each formulation type while it can produce fatal toxic effects, allergies and various other effects on the nervous system $[12,13]$. Benzyl alcohol is quantitatively estimated in raw material and pharmaceutical preparations by gas chromatography, derivative spectrophotometry, HPLC, amperometric enzyme electrode, polarography and capillary electrokinetic chromatography [13]. A high performance liquid chromatographic method for simultaneous determination of bifonazole and benzyl alcohol in pharmaceutical formulations is also reported [13]. In another report a HPLC method for simultaneous determination of benzyl alcohol and deslorelin [14] is described. To the best of our knowledge no analytical method is available for the simultaneous determination of amcinonide and benzyl alcohol in pharmaceutical preparations. Therefore, it was considered necessary to develop a HPLC method for the quantification of these compounds in pharmaceutical samples.

In the context of developing new quantitative determination procedures for natural constituents and drugs in body fluids using HPLC and capillary electrophoresis techniques we report various methods [15].

We wish to describe herein a simple, rapid, economical, and accurate method of analysis using reversed-phase HPLC (RP-HPLC) to simultaneously determine amcinonide and 
benzyl alcohol in pharmaceutical preparations and also the validation of this newly developed method. To the best of our knowledge this is for the first example of simultaneously determination of this type.

\section{MATERIALS AND METHODS}

HPLC grade acetonitrile and water (E. Merck, Darmstadt, Germany) were used for the HPLC analysis. Amcinonide and benzyl alcohol were USP reference standards.

\section{Apparatus and Chromatographic Conditions}

A Shimadzu 6 A system (Shimadzu, Tokyo, Japan), comprising a LC-6A pump, a SCL-6A system controller, a SIL-6A auto-injector, a SPD-6A, an UV-detector and C-R6A chromatopac was used. The column configuration was a Zorbax ODS reversed-phase column $(5 \mu \mathrm{m}, 250 \times 4.6 \mathrm{~mm})$ with a RP8 RPGU (Shimadzu, Tokyo, Japan), guard column $(10 \mu \mathrm{m}, 10 \times 4.6 \mathrm{~mm})$. An aliquot of $20 \mu \mathrm{l}$ was chromatographed.

The detection wavelength was set at $240 \mathrm{~nm}$. The flow rate was $1.5 \mathrm{ml} / \mathrm{min}$ and the separation was performed at ambient temperature. The mobile phase consisted of a degassed filtered mixture of acetonitrile and water $(70: 30 \%$ $\mathrm{v} / \mathrm{v})$.

\section{Preparation of Standard Solution}

Accurately weighed $20 \mathrm{mg}$ of amcinonide and $400 \mathrm{mg}$ of benzyl alcohol were transferred into a $100 \mathrm{ml}$ volumetric flask dissolved in $50 \mathrm{ml}$ of mobile phase with sonication for 5 minutes and made up to volume with mobile phase. An aliquot of $5 \mathrm{ml}$ of this solution was transferred into a $50 \mathrm{ml}$ volumetric flask and diluted to volume with a mixture of acetonitrile water $(70: 30 ; \mathrm{v} / \mathrm{v})$. The solution was filtered through a $0.45 \mu \mathrm{m}$ membrane filter before injection.

\section{Sample preparation}

A pharmaceutical sample containing amcinonide and benzyl alcohol, equivalent to $2 \mathrm{mg}$ and $40 \mathrm{mg}$, respectively, was weighed and transferred into a $100 \mathrm{ml}$ volumetric flask. The contents of the flask were dispersed in $30 \mathrm{ml}$ of a mixture of acetonitrile and water $(70: 30 ; \mathrm{v} / \mathrm{v})$ with heating on a water bath at a temperature not exceeding $50{ }^{\circ} \mathrm{C}$ for 5 minutes. While the flask was hot, $50 \mathrm{ml}$ of the same solvent mixture was added and the materials were dissolved by sonication for 5 minutes and made up to volume with the same solvent mixture. The solution was filtered through a Whatman No. 541 filter paper and then through a $0.45 \mu \mathrm{m}$ membrane filter before injection.

\section{RESULTS AND DISCUSSIONS}

Standard solutions of amcinonide and benzyl alcohol containing 50, 60, 70, 80, 90, 100, 120, 130, 140 and $150 \%$ of theoretical assay concentration $(20 \mathrm{mg} / \mathrm{ml}$ and $400 \mathrm{mg} / \mathrm{ml})$ were examined by the proposed HPLC method. A linear relation was observed between peak area and concentration. Fig. (1) shows a typical chromatogram.

Regression analysis of the calibration data $(n=3)$ was carried out and the value of slope, intercept and correlation co-efficient for each calibration curve were calculated (Table 1).

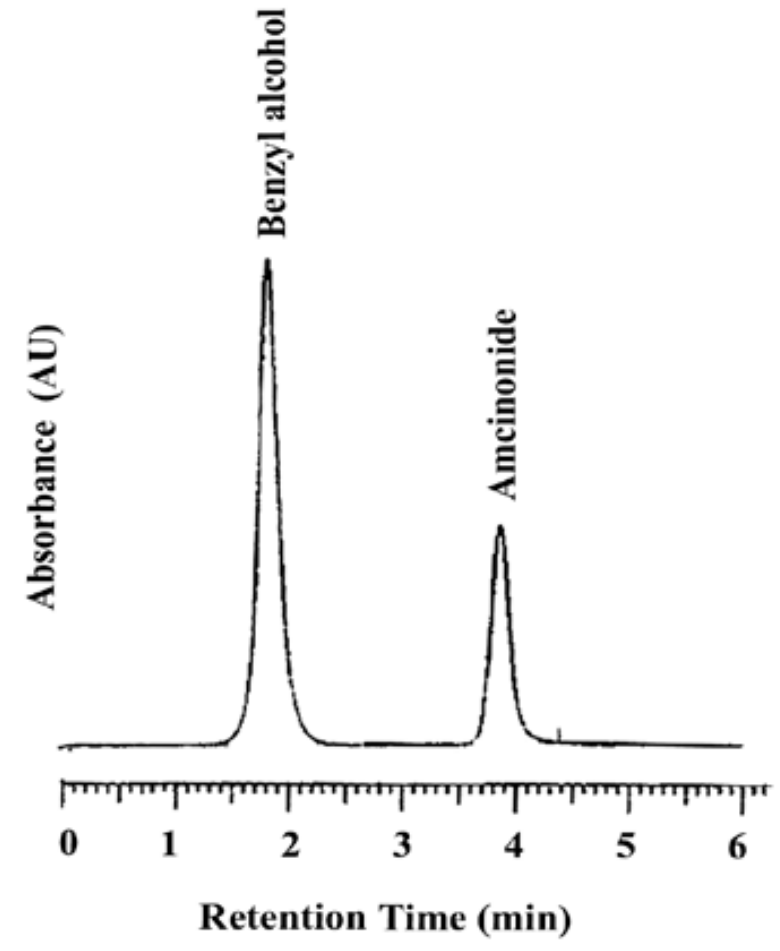

Fig. (1). Chromatogram of an authentic mixture containing 20 $\mathrm{mg} / \mathrm{ml}$ amcinonide and $400 \mathrm{mg} / \mathrm{ml}$ benzyl alcohol. Chromatographic conditions: Instrumentation: a Shimadzu 6 A system (Schimadzu, Tokyo, Japan), comprising a LC-6A pump, a SCL-6A system controller, a SIL-6A auto-injector, a SPD-6A, an UVdetector and a C-R6A chromatopac; a Zorbax reversed-phase column $(5 \mu \mathrm{m}, 250 \times 4.6 \mathrm{~mm})$; temperature: ambient; mobile phase: water/ aceto-nitrile $(70: 30, \mathrm{v} / \mathrm{v})$; linear gradient elution; flow rate: $1.5 \mathrm{ml} / \mathrm{min}$; detection: $U V, \lambda=254 \mathrm{~nm}$.

Table 1. Regression Analysis of the Calibration Data

\begin{tabular}{|c|c|c|c|}
\hline Drug & Slope & Intercept & $\begin{array}{c}\text { Correlation } \\
\text { Coefficient }\left(\mathbf{r}^{2}\right)\end{array}$ \\
\hline \hline Amcinonide & 2245.8881 & 11616.5454 & 0.9997 \\
\hline Benzyl alcohol & 2005.4363 & 10111.6363 & 0.9997 \\
\hline
\end{tabular}

Average of three experiments.

The validity of the proposed method was tested by the assay of an authentic mixture containing known quantities of amcinonide and benzyl alcohol in pharmaceutical formulations at 80, 100 and 120\% level of theoretical assay concentration. The results showed good accuracy (as revealed by the percentage recovery, see Table 2 ), which clearly demonstrates that placebo of the formulation is not interfering with the assay method.

Precision was assessed by injecting the standard solution five times and by the five times assay of a homogeneous sample. The results obtained were found to be statistically valid (Tables 3 and $\mathbf{4}$ ).

To determine the robustness of the method, the stability of the analytes was investigated. They were found to be stable in solution at ambient temperature for three days after their preparation with out losses as given in Table $\mathbf{5}$. 
Table 2. Simultaneous Determination of Amcinonide and Benzyl Alcohol

\begin{tabular}{|c|c|c|c|c|c|}
\hline \multicolumn{3}{|c|}{ Amcinonide } & \multicolumn{3}{|c|}{ Benzyl Alcohol } \\
\hline $\begin{array}{l}\text { Amount } \\
\text { Added } \\
(\mathrm{mg} / \mathrm{g})\end{array}$ & $\begin{array}{c}\text { Amount } \\
\text { Found } \\
\text { (mg/g) }\end{array}$ & $\begin{array}{c}\text { Recovery } \\
(\%)\end{array}$ & $\begin{array}{l}\text { Amount } \\
\text { Added } \\
(\mathrm{mg} / \mathrm{g})\end{array}$ & $\begin{array}{l}\text { Amount } \\
\text { Found } \\
\text { (mg/g) }\end{array}$ & $\begin{array}{c}\text { Recovery } \\
(\%)\end{array}$ \\
\hline 0.8036 & 0.8001 & 99.57 & 16.0210 & 15.9713 & 99.69 \\
\hline 0.8020 & 0.8010 & 99.87 & 16.1320 & 15.8012 & 97.95 \\
\hline 1.0230 & 1.0281 & 100.37 & 20.2016 & 20.1021 & 99.50 \\
\hline 1.0243 & 1.0050 & 98.81 & 20.4118 & 19.6101 & 96.07 \\
\hline 1.0186 & 0.9901 & 97.72 & 20.3268 & 20.1248 & 99.01 \\
\hline 1.0034 & 0.9710 & 96.77 & 20.4219 & 20.0175 & 98.02 \\
\hline 1.2030 & 1.1926 & 99.14 & 24.3011 & 23.8614 & 98.82 \\
\hline 1.2328 & 1.2528 & 101.64 & 24.1059 & 23.7823 & 98.87 \\
\hline \multicolumn{2}{|c|}{ Mean } & 99.24 & \multicolumn{2}{|c|}{ Mean } & 98.49 \\
\hline \multicolumn{2}{|c|}{$\mathrm{SD}$} & 1.42 & \multicolumn{2}{|c|}{ SD } & 1.08 \\
\hline \multicolumn{2}{|c|}{$\%$ RSD } & 1.43 & \multicolumn{2}{|c|}{$\%$ RSD } & 1.10 \\
\hline
\end{tabular}

Table 3. Precision of Standard Solution Measurements

\begin{tabular}{|c|c|c|}
\hline S. No. & $\begin{array}{c}\text { Peak Area for } \\
\text { Amicinonide (a.u.) }\end{array}$ & $\begin{array}{c}\text { Peak Area for Benzyl } \\
\text { Alcohol (a.u.) }\end{array}$ \\
\hline \hline 1 & 37503 & 61973 \\
2 & 37721 & 61924 \\
3 & 37383 & 61093 \\
4 & 38504 & 61842 \\
5 & 38802 & 61936 \\
\hline Mean & 37982 & 61753 \\
\hline SD & 632 & 372 \\
\hline \%RSD & 1.7 & 0.6 \\
\hline
\end{tabular}

Table 4. Precision of Test Sample Measurement

\begin{tabular}{|c|c|c|}
\hline S. No. & $\begin{array}{c}\text { Peak Area for } \\
\text { Amicinonide (a.u) }\end{array}$ & $\begin{array}{c}\text { Peak Area for } \\
\text { Benzyl Alcohol (a.u) }\end{array}$ \\
\hline \hline 1 & 99.20 & 100.35 \\
2 & 97.31 & 101.00 \\
3 & 98.46 & 102.00 \\
4 & 99.38 & 103.10 \\
5 & 98.31 & 103.21 \\
\hline Mean & 98.53 & 101.93 \\
\hline SD & 0.82 & 1.26 \\
\hline \%RSD & 0.84 & 1.24 \\
\hline
\end{tabular}

Intermediate precision of the method was examined by two different operators. Each carried out three determinations of the same batch using the described HPLC method. The results are given in Table 6. The developed HPLC method has been found to be time-saving as it provides the analysis of two compounds simultaneously with a high degree of precision and accuracy.

Table 5. Robustness of the Method

\begin{tabular}{|c|c|c|}
\hline Time Period (h) & Amcinonide (\%) & Benzyl Alcohol (\%) \\
\hline \hline 0 & 98.25 & 103.16 \\
24 & 97.58 & 101.52 \\
48 & 98.47 & 103.28 \\
\hline
\end{tabular}

Table 6. Intermediate Precision of the Method

\begin{tabular}{|c|c|c|c|}
\hline Operator & Determination & Amcinonide (\%) & Benzyl Alcohol (\%) \\
\hline \hline \multirow{3}{*}{ A } & 01 & 99.00 & 103.50 \\
& 02 & 97.20 & 101.31 \\
& 03 & 98.32 & 103.02 \\
\hline \multirow{3}{*}{ B } & 01 & 99.38 & 100.35 \\
& 02 & 98.48 & 102.02 \\
& 03 & 99.36 & 104.10 \\
\hline \multicolumn{2}{|c|}{ Mean } & 98.62 & 102.38 \\
S.D & 0.82 & 1.42 \\
\multicolumn{2}{|c|}{ \% RSD } & 0.84 & 1.38 \\
\hline \multicolumn{2}{|c|}{}
\end{tabular}

The limits of detection (LOD) are for amcinonide and benzyl alcohol $2 \mu \mathrm{g} / \mathrm{ml}$ and $10 \mu \mathrm{g} / \mathrm{ml}$ whereas the limits of quantization (LOQ) lie within the range of $4-30 \mu \mathrm{g} / \mathrm{ml}$ and $80-600 \mu \mathrm{g} / \mathrm{ml}$, respectively.

\section{CONCLUSIONS}

This paper describes a simple, rapid, economic, and accurate method of analysis using reversed-phase HPLC (RPHPLC) for the simultaneous determination of amcinonide and benzyl alcohol in pharmaceutical preparations. A validation of this analytical method was carried out and showed that specificity, robustness and precision are guaranteed. In addition, linearity is ensured for contents between 4-30 and $80-600 \mu \mathrm{g} / \mathrm{ml}$ of amicinonide and benzyl alcohol, respectively, and the recovery was calculated to be in the range of 99 to $100 \%$. The developed HPLC method is therefore appropriate for simultaneous and quantitative determinations of amicinonide-benzyl alcohol mixtures for quality assurance and R\&D laboratories of pharmaceutical and cosmetic industries.

\section{ACKNOWLEDGEMENTS}

We are thankful to Third World Academy of Sciences (TWAS), Italy (Grant No. 01-310 RG/CHE/AS) for financial assistance. Dr. Khalid Mohammed Khan and Dr. Shahnaz Perveen are thankful to Deutscher Akademischer Austauschdienst (DAAD, Bonn, Germany) for a short term scholarship.

\section{REFERENCES}

[1] Elks, J.; Ganellin, C.R. Dictionary of Drugs, $1^{\text {st }}$ ed.; Chapman \& Hall: New York, 1990.

[2] Woodford, R.; Haigh, J.M. Bioavailability and activity of $0.1 \%$ amcinonide preparations: comparison with proprietary topical cor- 
ticosteroid formulations of differing potencies. Curr. Ther. Res., 1979, 26, 301-310.

[3] Quevedo, W.C. Jr.; Holstein, T.J.; Dyckman, J.; Nordlund, J.J. Influence of depigmenting chemical agents on hair and skin color in yellow (pheomelanic) and black (eumelanic) mice. Pigm. Cell Res., 1990, 3, 71-79.

[4] Adachi, H.; Matsumoto, N.; Oshima, K.; Kurosawa, Y. Release of ingredients from corticosteroids ointments (I): stability and release of corticosteroids in commercial ointments admixed with boric acid and zinc oxide ointment. Byoin Yakugaku, 1987, 13, 137-142; Chemical Abstract, 107: 161561b (1987).

[5] Eisen, D. Method of treatment using mouthwashes containing steroids and antifungal agents and composition of matter. U.S. 5,310,545 (1994); Chemical Abstract, 121: 42455Z (1994).

[6] Pfaff, D.W.; Donald, W. Features of a hormone-driven defined neural circuit for mammalian behavior. Principles illustrated neuroendocrine syllogism, and multiplicative steroid effects. Ann. N. Y. Acad. Sci., 1989, 563, 131-147.

[7] United State Pharmacopoeia, $25^{\text {th }}$ ed.; 12601 Twinbrook Parkway, Rockville, MD, 2002; p. 103.

[8] Nagatani, K.; Oishi, T.; Iwasaki, S.; Takata, S.; Takagi, S. Oinment mixture 2. Concentration change of steroids in the mixture. $\mathrm{Hi}$ roshima-Ken Byoin Yakuzaishikai Gakujutsu Nenpo, 1986, 20, 1215; Chemical Abstract, 106: 9268h (1987).

[9] Van de Vaart, F.J.; Hulshoff, A.; Indemans, A.W.M. Analysis of creams. Part I. Application of thin layer chromatography. Pharm. Weekbl. Sci. Ed., 1983, 5, 109-113.

[10] Van de Vaart, F.J.; Hulshoff, A.; Indemans, A.W.M. Analysis of creams. Part II. Application of thin layer chromatography. Pharm. Weekbl. Sci. Ed., 1983, 5, 113-118.

[11] Rego, A.; Nelson, B. Simultaneous determination of hydrocortisone and benzyl alcohol in pharmaceutical formulations by reversed-phase high-pressure liquid chromatography. J. Pharm. Sci., 1982, 71, 1219-1223.

[12] Sweetman, S. In Martindale: The complete drug references, $33^{\text {rd }}$ ed.; Pharmaceutical Press, London, 2002.

[13] Čudina, O.A.; Čomor, M.I.; Janković, I.A. Simultaneous determination of bifonazole and benzyl alcohol in pharmaceutical formulations by reversed-phase HPLC. Chromatographia, 2005, 61, 415418, and references quoted therein.

[14] Wood, G.C.; Iyer, M.R.; Geller, A.M.; Fleischner, A.M.; Sheth, B.B. A high pressure liquid chromatography assay method for analysis of deslorelin and benzyl alcohol in deslorelin injection. $J$. Liq. Chromatogr. Relat. Technol., 1998, 21, 2183-2190.

[15] a) Franz, M.; Vollmer, S.; Wacker, R.; Jäger, S.; Scheer, R.; Stoeva, S.; Voelter, W. Isolation and quantification of chitinbinding mistletoe lectin from mistletoe extract and validation of this method. Arzneim.-Forsch./Drug Res., 2004, 54, 230-239. b) Friess, U.; Waldner, M.; Wahl, H.-G.; Lehmann, R.; Haering, H.U.; Voelter, W.; Schleicher, E. Liquid chromatography-based determination of urinary free and total $N$ (epsilon)-(carboxymethyl) lysine excretion in normal and diabetic subjects. J. Chromatogr. B, 2003, 794, 273-280. c) Khan, A.R.; Khan, K.M.; Perveen, S.; Butt, N. Determination of nicotinamide and 4-aminobenzoic acid in pharmaceutical preparations by liquid chromatography. J. Pharm. Biomed. Anal., 2002, 29, 723-727. d) Friess, U.; Lehmann, R.; Weigert, C.; Haering, H.-U.; Voelter, W.; Schleicher, E. Single-run determination of adenylate nucleotides, and of cellular energy status, by a simple and improved capillary electrphoretic method. Chromatographia, 2002, 56, 375-378. e) Voelter, W.; Stoeva, S.; Echner, H.; Schütz, J.; Lehmann, R.; Häring, H.-U.; Schleicher E.; Mullen, A.M.; Casserly, U.; Troy, D.J.; Tsitsilonis, O.E.; Lymberi, P.; Baxevanis, C.N.; Papamichail, M. Analytical tools for rapid, sensitive, quantitative identification of potential meat quality markers. J. Prakt. Chem., 2000, 342, 179-191. f) Liebich, H.M.; Lehmann, R.; Weiler, A.E.; Grübler, G.; Voelter, W. Capillary electrophoresis, a rapid and sensitive method for routine analysis of apolipoprotein A-I in clinical samples. J. Chromatogr. A, 1995, 717, 25-31. g) Krämer, P.; Wincierz, U.; Grübler, G.; Tschakert, J.; Voelter, W.; Mayer, H. Rational approach to fractionation, isolation, and characterization of polysaccharides from the lichen Cetraria islandica. Arzneim.-Forsch./Drug Res., 1995, 45, 726-731. h) Grübler, G.; Voelter, W.; Henke, H.; Mayer, H. Der Strukturbeleg für Dequalinium. Pharm. Ind., 1990, 52, 794-800. i) Buchele, A.; Schloz, U.; Müller-Wellensiek, A.; Voelter, W. Metabolisierungs-studien von 5-Ethyl-2'-desoxyuridin mit Leberextrakt, Leberzellen und Leberzellkulturen. Arzneim.-Forsch./Drug Res., 1989, 39, 220-222. j) Voelter, W.; Zech, K.; Arnold, P.; Ludwig, G. Determination of selected pyrimidines, purines and their metabolites in serum and urine by reversed-phase ion-pair chromatography. J. Chromatogr., 1980, 199, 345-354. k) Voelter, W.; Bauer, H. Separation of synthetic mixtures of sugars and of sugars in body fluids with a high-resolution carbohydrate analyzer. Clin. Chem., 1975, 21, 1882-1886.

(C) Khan et al.; Licensee Bentham Open.

This is an open access article licensed under the terms of the Creative Commons Attribution Non-Commercial License (http://creativecommons.org/licenses/by$\mathrm{nc} / 3.0 /$ ) which permits unrestricted, non-commercial use, distribution and reproduction in any medium, provided the work is properly cited. 